\title{
Antibacterial and antibiofilm activity of Ammi majus seed against Gram-positive bacteria
}

Abstract
used in a different country traditionally for treatment bacterial infection. This study aimed to investigate in vitro antibacterial and antibiofilm activity of Ammi majus seed extracts against six isolated Gram-positive bacteria.

Methods: The antibacterial activity of seed extracts were screened by disk diffusion and agar overlay bioautography method and their activities were further determined by minimum inhibitory and minimum bactericidal concentration. Biofilm formation was evaluated by the microtiter plate crystal violet assay. The quantity of bound bacteria was determined by measuring absorbance at (OD630 nm) using microtiter plate reader.

Results: Ethanol $80 \%$ and ethyl acetate extracts showed variable activity against all isolated bacteria while petroleum ether extract revealed resistance against studied bacteria. Streptococcus mitis showed more pronounced sensitivity against both extracts by disk diffusion $(12 \mathrm{~mm}$ and $10 \mathrm{~mm}$ ) and bioautography method with minimum inhibitory concentration $7.8125 \mathrm{mg} / \mathrm{ml}$ of ethanol $80 \%$ and $15.625 \mathrm{mg} / \mathrm{ml}$ for ethyl acetate extracts. Ethanol $80 \%$ and ethyl acetate extract significantly reduced biofilm formation as compared to control, showed antibiofilm activity at $0.4883-62.5 \mathrm{mg} / \mathrm{ml}$ and exhibited strongest antibiofim activity against Staphylococcus aureus.

Conclusion: Ammi majus seed extracts revealed highest antibacterial activity against Streptococcus species and strongest antibiofilm activity on Staphylococcus species.

Keywords: Ammi majus; Disk diffusion; Bioautography; minimum inhibitory concentration; Antibiofilm.

\section{Introduction}

Plants and their metabolites have a long history of use in folk medicine for the prevention and treatment of diseases and infection. ${ }^{1}$ Treatment of infectious diseases lead to development excessive use of antibacterial agents which resulted in the antibacterial resistant which increase the chance of treatment failure. Antibacterial resistance due to accepting of resistance genes by horizontal gene transfer, target alteration of drugs, low permeability systems and grow in a specific growth state like biofilm are important mechanisms involved in bacterial resistance. ${ }^{2}$ Bacterial biofilm is a sessile life form defined as community of microorganisms attached to a biotic or abiotic substrate surface and submerged into extracellular slimy matrix. ${ }^{3}$ Bacterial biofilms have been reported to have useful effects on food chains, sewage treatment plants, on other hand have harmful effects serves to encourage bacteria persistence by resisting antibacterial treatment and host immune responses. ${ }^{4}$ Biofilm causes numerous infections such as chronic otitis media, chronic prostatitis, chronic pneumonia in patients with cystic fibrosis, infections of orthopedic devices. ${ }^{5,6}$ The factors that are contributed to resistance in biofilm forming bacteria includes the slow growth rate, decreased diffusion of antimicrobials and accumulation of enzymes that are involved in the resistance. ${ }^{2}$ Approximately 60\% of human infections are reported to be

* Department of Pharmacognosy, College of Pharmacy, Hawler Medical University, Erbil, Iraq. 
a result of biofilm formation on the human mucosa. As a result, lead to increased interest in the search to identify the alternatives therapy for microbial control $^{7}$ and almost exclusively focused on the effects of these against planktonic biofilm forms that are more resistant to antimicrobial agents and therefore more difficult to control. ${ }^{8}$ Some plants have been reported to be able to prevent the formation of biofilm in some bacteria such as Staphylococcus epidermidis, Staphylococcus aureus, Staphylococcus auricularis, Streptococcus mitis, Streptococcus salivarius, Streptococcus pneumoniae..$^{9-11}$ Among plants of the Apiaceae, family Ammi majus native to northern Africa, southern Europe, western Asia and India. The fruit laterally compressed, oblong, mericarps of the cremocarp separated by a carpophore. Seed small, pendulous, albuminous. ${ }^{12}$ The seed contains furanocoumarins, flavonoids, phenolic acid and other constituents. ${ }^{13,14}$ The plant is reported to possess antimicrobial, antischistosomal, anti-inflammatory, antioxidant and antitumor activities. ${ }^{14-16}$ To our knowledge and from searching literature, there are only a few studies on antibacterial activity and no study on antibiofilm activity of Ammi majus seed. This study aimed to investigate in vitro antibacterial activity and for the first time the antibiofilm activity of Ammi majus seed extracts against six isolated Gram-positive bacteria.

\section{Methods}

\section{Materials}

Petroleum ether, ethyl acetate, and ethanol from Scharlab S.L. (Spain), Muller Hinton agar, Blood agar, Nutrient agar, Nutrient broth (Merck Co. Germany). $0.1 \%$ (v/w) Crystal Violet (Sigma-Aldrich, Germany), Dimethylthiazolyl diphenyl tetrazolium bromide (MTT) (Taizhou xi Anju pharma.co., China).

\section{Sample collection and extraction}

The fresh seed of Ammi majus was collected during July 2014 from Kurdistan region, Iraq, washed with distilled water and shade dried for 15 days, coarsely powdered and stored in moisture proof and light proof bottles at $6{ }^{\circ} \mathrm{C}$ until used. The identity of the plant was confirmed by the Department of Pharmacognosy, College of Pharmacy, Hawler Medical University. The $100 \mathrm{gm}$ powdered seed was extracted with petroleum ether using ultrasonic (LUC-405, Korea) assisted extractor for $1 \mathrm{~h}$ at $40{ }^{\circ} \mathrm{C}{ }^{17}$ then filtered. The residual plant materials were dried and re-extracted with ethanol $80 \%$ for $1 \mathrm{~h}$ after filtration that yielded an extract which was after drying half of it dissolved in $10 \mathrm{ml}(5 \mathrm{~N}) \mathrm{HCl}$ and refluxed for 1 hour. Liquid-liquid fractionation using ethyl acetate $(10 \times 3 \mathrm{ml})$ resulted in an ethyl acetate fraction on drying in vacuum the three fraction used for evaluation of the antibacterial and antibiofilm activity.

\section{Microorganisms and inoculums preparation}

The antibacterial activity of seed extracts was assessed against 6 Gram-positive bacteria which include Staphylococcus epidermidis, Staphylococcus aureus, Staphylococcus auricularis, Streptococcus mitis, Streptococcus salivarius, Streptococcus pneumoniae. The isolated pathogenic bacteria from urine were used in this work identified and confirmed by morphological studies and by using biochemical tests in the Microbiological Laboratory of the Biological Department, College of Education, Salahadin University. All bacteria were grown on Muller Hinton and Blood agar at $37{ }^{\circ} \mathrm{C}$ for $24 \mathrm{~h}$, then stored at $4{ }^{\circ} \mathrm{C}$ until used. Individual pure colonies from each isolated plate were transferred to $10 \mathrm{ml}$ Nutrient broth media. The study approved by the ethics committee of College of Pharmacy, Hawler Medical University, Erbil, Iraq.

\section{Determination of antibacterial activity Agar disc diffusion method} The agar disc diffusion method ${ }^{18}$ was employed to determine the antibacterial activities of petroleum ether, ethanol $80 \%$ and ethyl acetate extracts of Ammi majus seed against 6 Gram-positive bacteria. The bacterial cultures were first grown on 
Nutrient and blood agar plates at $37^{\circ} \mathrm{C}$ for 18 to $24 \mathrm{~h}$. One or several colonies of the respective bacteria were transferred into normal saline and adjusted to 0.5 McFarland turbidity standards. The inocula of the respective bacteria were streaked on Muller Hinton agar plates using a sterile swab and were then dried at $37^{\circ} \mathrm{C}$ during $15 \mathrm{~min}$. A sterile filter disc having $6 \mathrm{~mm}$ of diameter were soaked in different concentration 250,125 and $62.5 \mathrm{mg} / \mathrm{ml}$ of each extract separately was placed at the surface of Muller-Hinton agar plates. The plates were incubated for $24 \mathrm{~h}$ at $37^{\circ} \mathrm{C}$, following incubation the plates were observed. The antibacterial activity was evaluated by measuring the clear zone surrounding the Whatman paper. Standard discs of the antibiotic azithromycin were applied as positive antibacterial controls.

\section{Agar overlay bioautography method}

A thin layer chromatography (TLC) was used to separate bioactive constituents of ethanol $80 \%$ and ethyl acetate extracts. $200 \mu \mathrm{L}$ both ex-tracts were applied on pre-coated silica gel GF254 TLC plate (Merck), the best solvent system was applied for bioautography was Toluene: ethyl acetate: formic acid: water (10: 80: 2.5: 2.5 ) and dried for complete removal of solvents, then overlaid by Muller Hinton agar seed-ed with an overnight culture of isolated bacteria. The plate was incubated at $37{ }^{\circ} \mathrm{C}$ for 24 hours after that sprayed with an aqueous solution of $2 \mathrm{mg} / \mathrm{ml}$ dimethyl thiazolyl diphenyl tetrazolium bromide (MTT). The areas of inhibition were pale or yellow on a purple colored background. ${ }^{19}$

Determination of minimal inhibitory and minimal bactericidal concentration

The minimal inhibitory concentration (MIC) of Ammi majus extracts against each isolated bacteria was determined using broth microdilution assay as modified briefly, two-fold serial dilutions of ethanol $80 \%$ and ethyl acetate extracts were prepared with Nutrient broth at a total volume of $100 \mu \mathrm{l}$ per well in the 96-well plates. They started from the lowest concentrations of each extract $62.5 \mathrm{mg} / \mathrm{ml}$. The microtiter plate wells were inoculated with $10 \mu \mathrm{l}$ of $0.5 \mathrm{McF}$ arland for each bacteria per well. After overnight incubation at $37^{\circ} \mathrm{C}$ appropriate conditions, absorbance was measured at $490 \mathrm{~nm}$ using a microtiter plate reader ( ELX800 Biotech USA ) to assess the cell growth. The negative control consisted of Nutrient broth and bacterial cell suspension without the extract. Blank control contained only the medium. The MIC endpoint was defined as the lowest concentration of the test agent that completely inhibited growth or produced at least $90 \%$ reduction of absorbance in comparison to the negative control. All experiments were performed in triplicate and the average values were reported as MIC. The minimal bactericidal concentration (MBC) was defined as the lowest concentration of wells that did not allow visible growth when $10 \mu \mathrm{l}$ of the well contents was placed on agar and grown 24 hours at $37^{\circ} \mathrm{C}$ in appropriate conditions. ${ }^{20}$

\section{Determination of antibiofilm activity}

The effect of Ammi majus seed extracts on biofilm formation of each isolated pathogen Staphylococcus epidermidis, Staphylococcus aureus, Staphylococcus auricularis, Streptococcus mitis, Streptococcus salivarius, Streptococcus pneumoniae was examined using the modified crystal violet assay method. ${ }^{21}$ Twofold serial dilutions of plant extract were made in sterile 96 flat wells microtiter plates containing $100 \mu \mathrm{l}$ of Nutrient broth per well. The tested concentration ranged from (0.4883-62.5) $\mathrm{mg} / \mathrm{ml}$ for ethanol $80 \%$ and ethyl acetate fraction. A $10 \mu \mathrm{l}$ of fresh bacterial suspension adjusted with (0.5 McFarland) was added to each well. Positive control (bacterial suspension in broth) and negative control (extract in broth). Following incubation at $37^{\circ} \mathrm{C}$ for 24 hours, the content of each well was gently removed and unbound bacterial cells were removed from all wells by washing three times with $200 \mu \mathrm{l}$ of sterile distilled water, stained with $0.1 \%$ crystal violet and incubated at the room temperature for 
30 minutes. Excess stain was removed thorough washing with distilled water and plates were fixed with $200 \mu \mathrm{l}$ of ethanol $70 \%$ for recording absorbance at $630 \mathrm{~nm}$ using an ELISA microplate reader.

The inhibition percentage of biofilm was calculated by the formula ${ }^{21}$

Percentage of biofilm inhibition $=($ Control OD630 nm-Test OD630 nm) / Control OD630 nm) x 100

\section{Statistical analysis}

Anti-biofilm and anti-bacterial activity data were obtained in triplicate and the results analyzed statistically by ANOVA using the statistical package for the social sciences (version 17.0). A $P$ value of $\leq 0.05$ was considered to indicate statistical significance.

\section{Results}

Antibacterial activity of seed extracts

In present work petroleum ether, ethanol
$80 \%$ and ethyl acetate extracts of Ammi majus seed evaluated for their antibacterial activity by disc diffusion assay are presented in Table 1. All isolated Gram-positive pathogen revealed completely resistance to petroleum ether extract while susceptible to ethanol $80 \%$ and ethyl acetate extracts of Ammi majus seed with variable degrees of inhibition zones. The diameter inhibition zone of ethanol $80 \%$ and ethyl acetate extract at $62.5 \mathrm{mg} / \mathrm{ml}$ ranged from $(5-12 \mathrm{~mm})$ and $(3-10 \mathrm{~mm})$ with the highest activity against Streptococcus mitis, along with MIC and MBC value for both extracts ranged from $(3.9063-15.625 \mathrm{mg} / \mathrm{ml})$ and $(7.8125-31.25 \mathrm{mg} / \mathrm{ml})$ respectively showed in Table 2.

Table 1: Diameter inhibition zone of Ammi majus seed extracts against Gram positive bacteria (Mean $\pm S D)$.

\begin{tabular}{|c|c|c|c|c|c|c|c|c|c|c|}
\hline \multirow{2}{*}{$\begin{array}{l}\text { Extract } \\
\text { Bacteria }\end{array}$} & \multicolumn{3}{|c|}{$\mathrm{PE}(\mathrm{mg} / \mathrm{ml})$} & \multicolumn{3}{|c|}{$\mathrm{E} 80 \%(\mathrm{mg} / \mathrm{ml})$} & \multicolumn{3}{|c|}{$\mathrm{E} \mathrm{a}(\mathrm{mg} / \mathrm{ml})$} & \multirow[b]{2}{*}{ Azi } \\
\hline & 250 & 120 & 62.5 & 250 & 125 & 62.5 & 250 & 125 & 62.5 & \\
\hline $\begin{array}{l}\text { Staphylococcus } \\
\text { epidermidis }\end{array}$ & $\mathrm{R}$ & $\mathrm{R}$ & $\mathrm{R}$ & $12 \pm 0.015$ & $10 \pm 0.27$ & $7 \pm 0.980$ & $8 \pm 0.034$ & $5 \pm 0.118$ & $3 \pm 0.211$ & $32 \pm 0.209$ \\
\hline $\begin{array}{l}\text { Staphylococcus } \\
\text { aureus }\end{array}$ & $\mathrm{R}$ & $\mathrm{R}$ & $\mathrm{R}$ & $10 \pm 0.067$ & $9 \pm 0.300$ & $7 \pm 1.33$ & $10 \pm 0.012$ & $7 \pm 0.044$ & $5 \pm 0.580$ & $35 \pm 1.03$ \\
\hline $\begin{array}{l}\text { Staphylococcus } \\
\text { auricularis }\end{array}$ & $\mathrm{R}$ & $\mathrm{R}$ & $\mathrm{R}$ & $14 \pm 0.146$ & $10 \pm 0.01$ & $8 \pm 0.980$ & $15 \pm 0.150$ & $9 \pm 0.203$ & $7 \pm 0.123$ & $46 \pm 0.315$ \\
\hline $\begin{array}{l}\text { Streptococcus } \\
\text { mitis }\end{array}$ & $\mathrm{R}$ & $\mathrm{R}$ & $\mathrm{R}$ & $20 \pm 0.122$ & $15 \pm 018$ & $12 \pm 0.13$ & $16 \pm 0.220$ & $14 \pm 0.01$ & $10 \pm 0.01$ & $30 \pm 0.231$ \\
\hline $\begin{array}{l}\text { Streptococcus } \\
\text { salivarius }\end{array}$ & $\mathrm{R}$ & $\mathrm{R}$ & $\mathrm{R}$ & $10 \pm 0.201$ & $7 \pm 0.267$ & $5 \pm 0.014$ & $12 \pm 0.032$ & $7 \pm 0.201$ & $5 \pm 0.380$ & $12 \pm 0.197$ \\
\hline $\begin{array}{l}\text { Streptococcus } \\
\text { pneumoniae }\end{array}$ & $\mathrm{R}$ & $\mathrm{R}$ & $\mathrm{R}$ & $14 \pm 0.176$ & $8 \pm 0.139$ & $7 \pm 0.056$ & $10 \pm 0.071$ & $6 \pm 0.030$ & $4 \pm 0.087$ & $30 \pm 0.200$ \\
\hline
\end{tabular}

PE: Petroleum ether; E80 \%: Ethanol 80 \%; Ea: Ethyl acetate extract ; R: Resistance; Azi: Azithromycin

Table 2: Minimum inhibitory and minimum bactericidal concentration of Ammi majus seed extracts against Gram-positive bacteria.

\begin{tabular}{lcccc}
\hline \multirow{2}{*}{ Bacteria } & \multicolumn{2}{c}{ MIC (mg/ml) } & \multicolumn{2}{c}{ MBC (mg/ml) } \\
& E80\% & E a & E80\% & E a \\
\hline Staphylococcus epidermidis & 7.8125 & 7.8125 & 15.625 & 15.625 \\
Staphylococcus aureus & 15.625 & 15.625 & 31.25 & 31.25 \\
Staphylococcus auricularis & 7.8125 & 3.9063 & 15.625 & 15.625 \\
Streptococcus mitis & 7.8125 & 15.625 & 15.625 & 31.25 \\
Streptococcus salivarius & 3.9063 & 15.625 & 7.8125 & 31.25 \\
Streptococcus pneumoniae & 7.8125 & 15.625 & 15.625 & 31.25 \\
\hline \hline
\end{tabular}


https://doi.org/10.15218/zjms.2017.018

The results of agar overlay bioautography showed the presence of one or more active constituents in seed extracts responsible for antibacterial activity (Figure 1). In ethanol $80 \%$ extract four constituents were found to be active ethanol $80 \%$ extract $(E 80 \%) 1-4$ with retardation factor values $0.9,0.8,0.6$ and 0.5 , respectively. Constituent E80\% 1 showed activity against Staphylococcus epidermidis, Staphylococcus aureus, and Streptococcus salivarius. Constituent E80\% 2 showed activity against all isolated bacteria except Staphylococcus auricularis. Constituent
E80\% 3 showed activity against Staphylococcus aureus, Staphylococcus auricularis and Streptococcus pneumoniae. Constituent E80\% 4 showed activity against Staphylococcus auricularis, Streptococcus mitis, Streptococcus salivarius. In ethyl acetate extract three constituents ethyl acetate extract (Ea) 1, Ea 2 and Ea 3 at retardation factor values $0.8,0.6$ and 0.35 respectively were found to be active. Constituent $\mathrm{Ea} 1$ showed a zone of inhibition against all isolated bacteria, while Ea 2 and Ea 3 were found only active against Streptococcus mitis.
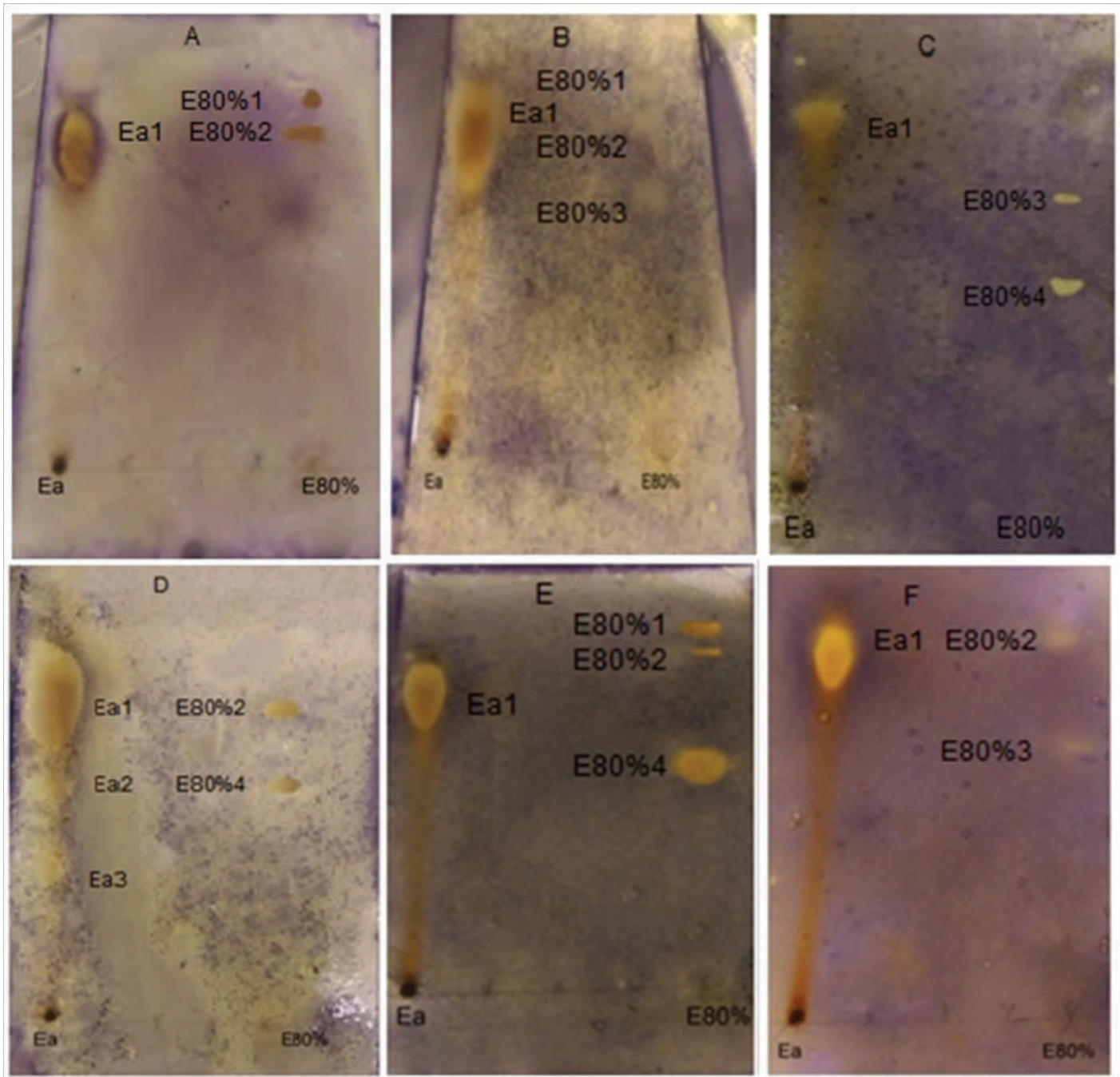

E80\%: Ethanol 80\%; Ea: Ethyl acetate extracts

Figure 1: Bioautogram plates of ethanol $80 \%$ and ethyl acetate extracts against A. Staphylococcus epidermidis B. Staphylococcus aureus C. Staphylococcus auricularis D. Streptococcus mitis E. Streptococcus salivarius F. Streptococcus pneumonia. 
Anti-biofilm activity of seed extracts

The antibiofilm activity of ethanol $80 \%$ and ethyl acetate seed extracts showed a significant reduction in the biofilm at different concentration ranged from $0.4883-62.5 \mathrm{mg} / \mathrm{ml}$ against six isolated bacteria were monitored by assaying crystal violet dye and the reduction in cell attachment was measured by a microplate reader. The inhibition of biofilm formation increased with increasing concentration (Table 3 and 4 ).

Table 3: Antibiofilm activity of ethanol $80 \%$ extract against Gram-positive bacteria.

\begin{tabular}{|c|c|c|c|c|c|c|c|c|c|c|c|c|}
\hline \multirow{3}{*}{$\begin{array}{l}\text { Ethanol } \\
80 \% \\
\text { extract }\end{array}$} & \multicolumn{12}{|c|}{ Percentage biofilm inhibition } \\
\hline & \multicolumn{2}{|c|}{ St.epidermidis } & \multicolumn{2}{|c|}{ St. aureus } & \multicolumn{2}{|c|}{ St. auricularis } & \multicolumn{2}{|c|}{ S. mitis } & \multicolumn{2}{|c|}{ S.salivarius } & \multicolumn{2}{|c|}{ S. pneumoniae } \\
\hline & $\%$ & $\begin{array}{c}P \\
\text { value }\end{array}$ & $\%$ & $\begin{array}{c}P \\
\text { value }\end{array}$ & $\%$ & $\begin{array}{c}P \\
\text { value }\end{array}$ & $\%$ & $P$ value & $\%$ & $\begin{array}{c}P \\
\text { value }\end{array}$ & $\%$ & $P$ value \\
\hline Control & 0 & & 0 & & 0 & & 0 & & 0 & & 0 & \\
\hline 0.4883 & 14.9 & 0.041 & 50.7 & 0.019 & 1.8 & 0.049 & 2.9 & 0.033 & 7 & 0.043 & 3 & 0.02 \\
\hline 0.9766 & 17.7 & 0.035 & 55.5 & 0.046 & 24.5 & 0.026 & 7.5 & 0.025 & 37.7 & 0.032 & 12.6 & 0.036 \\
\hline 1.9531 & 21.5 & 0.029 & 61.9 & 0.039 & 28.1 & 0.037 & 21.3 & 0.045 & 46.5 & 0.048 & 16.6 & 0.015 \\
\hline 3.9063 & 29.9 & 0.036 & 65 & 0.047 & 31.8 & 0.017 & 31.1 & 0.028 & 48.2 & 0.018 & 31.3 & 0.04 \\
\hline 7.8125 & 41.1 & $<0.001$ & 80.9 & $<0.001$ & 66.3 & $<0.001$ & 33.4 & $<0.001$ & 51.7 & $<0.001$ & 35.3 & $<0.001$ \\
\hline 15.625 & 48.5 & $<0.001$ & 87.3 & $<0.001$ & 75.4 & $<0.001$ & 35.4 & $<0.001$ & 57 & $<0.001$ & 41.4 & $<0.001$ \\
\hline 31.25 & 59.8 & $<0.001$ & 92 & $<0.001$ & 78.1 & $<0.001$ & 44.9 & $<0.001$ & 60.5 & $<0.001$ & 75.2 & $<0.001$ \\
\hline 62.5 & 71.9 & $<0.001$ & 95.2 & $<0.001$ & 81.8 & $<0.001$ & 55.4 & $<0.001$ & 70.1 & $<0.001$ & 89.8 & $<0.001$ \\
\hline
\end{tabular}

$P$ value represents the comparisons between control and different concentrations

Table 4: Antibiofilm activity of ethyl acetate extract against Gram-positive bacteria.

\begin{tabular}{|c|c|c|c|c|c|c|c|c|c|c|c|c|}
\hline \multirow{3}{*}{$\begin{array}{l}\text { Ethyl } \\
\text { acetate } \\
\text { extract }\end{array}$} & \multicolumn{12}{|c|}{ Percentage biofilm inhibition } \\
\hline & \multicolumn{2}{|c|}{ St.epidermidis } & \multicolumn{2}{|c|}{ St. aureus } & \multicolumn{2}{|c|}{ St. auricularis } & \multicolumn{2}{|c|}{ S. mitis } & \multicolumn{2}{|c|}{ S.salivarius } & \multicolumn{2}{|c|}{$\begin{array}{c}\text { S. } \\
\text { pneumoniae }\end{array}$} \\
\hline & $\%$ & $P$ value & $\%$ & $P$ value & $\%$ & $\begin{array}{c}P \\
\text { value }\end{array}$ & $\%$ & $\begin{array}{c}P \\
\text { value }\end{array}$ & $\%$ & $\begin{array}{c}P \\
\text { value }\end{array}$ & $\%$ & $\begin{array}{c}P \\
\text { value }\end{array}$ \\
\hline Control & 0 & & 0 & & 0 & & 0 & & 0 & & 0 & \\
\hline 0.4883 & 7.4 & 0.04 & 4.9 & 0.019 & 32.7 & 0.032 & 11.5 & 0.029 & 12.6 & 0.031 & 6.8 & 0.021 \\
\hline 0.9766 & 16.8 & 0.017 & 10.8 & 0.044 & 50 & 0.02 & 14.4 & 0.03 & 17.4 & 0.04 & 11.8 & 0.033 \\
\hline 1.9531 & 20.5 & 0.027 & 22.8 & 0.03 & 50.9 & 0.04 & 18.4 & 0.01 & 23.3 & 0.025 & 18 & 0.03 \\
\hline 3.9063 & 23.3 & 0.020 & 71 & 0.027 & 51.8 & 0.023 & 23.3 & 0.048 & 33 & 0.037 & 29.2 & 0.019 \\
\hline 7.8125 & 31.7 & 0.016 & 72.2 & 0.046 & 55.4 & 0.039 & 27.9 & 0.027 & 39.8 & 0.02 & 44 & 0.049 \\
\hline 15.625 & 52.3 & $<0.001$ & 78.3 & $<0.001$ & 68.1 & $<0.001$ & 38.4 & $<0.001$ & 55.3 & $<0.001$ & 57.7 & $<0.001$ \\
\hline 31.25 & 63.5 & $<0.001$ & 90.3 & $<0.001$ & 87.2 & $<0.001$ & 44.3 & $<0.001$ & 71.8 & $<0.001$ & 62.7 & $<0.001$ \\
\hline 62.5 & 73.8 & $<0.001$ & 93.9 & $<0.001$ & 90 & $<0.001$ & 59.3 & $<0.001$ & 87.3 & $<0.001$ & 85.7 & $<0.001$ \\
\hline
\end{tabular}

$P$ value represents the comparisons between control and different concentrations 


\section{Discussion}

This study included evaluation three Ammi majus seed extracts against 6 Gram-positive bacteria to determine their antibacterial and antibiofilm activities. Results of the antibacterial activity study demonstrated that ethanol $80 \%$ extract showed higher activity than ethyl acetate extract against bacterial species. In a comparison of microbial sensitivity to both extracts by disk diffusion assay, Streptococcus species presented more pronounced sensitivity to ethanol $80 \%$ and ethyl acetate extracts than Staphylococcus species. Petroleum ether extract did not show activity against 6 Gram-positive bacteria even at maximum concentration $250 \mathrm{mg} / \mathrm{ml}$, while ethanol $80 \%$ and ethyl acetate extract exhibited activity even at minimum concentration $62.5 \mathrm{mg} / \mathrm{ml}$ and more pronounced inhibition against Streptococcus mitis while the lowest inhibition for ethanol $80 \%$ extract was $5 \mathrm{~mm}$ against Streptococcus salivarius and for ethyl acetate extract was $3 \mathrm{~mm}$ against Staphylococcus epidermidis (Table 1). This may be because the bacterial inhibition can vary with plant extracts, the solvent used for extraction and the organism to be tested. $^{22}$ The antibacterial activity of ethanol $80 \%$ and ethyl acetate extract against Staphylococcus epidermidis and Staphylococcus aureus in agreement with the result recorded by other works, ${ }^{23}$ while in contrast with the same study about petroleum ether extract activity against same bacteria. The antibacterial activity of ethanol $80 \%$ and ethyl acetate extract against Staphylococcus auricularis, Streptococcus mitis, Streptococcus salivarius, Streptococcus pneumoniae has not been previously described. In this study, bioautography is an important and easy way for determination bioactive constituents responsible for antibacterial activity even in a complex matrix which is found in seed extracts. The bioautography assay was performed for extracts showed antibacterial activity by disk diffusion method, applied to 6 Gram-positive bacteria and microbial growth inhibition appeared as pale or yellow zones around constituents with antibacterial activity against a violet background. In ethanol $80 \%$ extract constituent E80\% 2 showed activity against five isolated bacteria while E80\% 1, 3 and 4 which revealed activity only against three bacteria. All isolated bacteria showed sensitivity to constituent Ea 1 of ethyl acetate extract but Staphylococcus aureus and Streptococcus mitis showed more pronounced sensitivity in comparison to other bacteria (Figure 1). The MIC value of the extracts were assessed visually and by microtiter plate reader methods in order to minimize error and the lowest MIC value was 3.9063 for ethanol $80 \%$ extract with MBC 7.8125 $\mathrm{mg} / \mathrm{ml}$ against Streptococcus salivarius, also for ethyl acetate extract against Staphylococcus auricularis with MBC $15.625 \mathrm{mg} / \mathrm{ml}$ (Table 2). Surprisingly, ethanol $80 \%$ and ethyl acetate extract have larger inhibition zones against Streptococcus mitis and lowest MIC value against Streptococcus salivarius and Staphylococcus auricularis; this may be due to the presence of bioactive constituents in extract which is difficult to spread on the agar surface, but when they are diluted in broth showed a high antibacterial activity. Most of the plant have been studied for their activity against bacterial infection for the development of new antimicrobial agents but few plant extract has been investigated for their antibiofilm activity and antibiofilm activity of Ammi majus seed has not been reported previously. The study was only conducted on the extracts demonstrating activity to the isolated bacteria. Results indicated that both extracts showed significant inhibition of biofilm $P<0.05$ at concentration $0.4883 \mathrm{mg} / \mathrm{ml}$ against isolated bacteria whereas after $3.9063 \mathrm{mg} / \mathrm{ml}$ showed significant reduction of biofilm formation with $P<0.001$ for ethanol $80 \%$ extract. Seed extracts exhibited stronger antibiofilm activity against Staphylococcus species than Streptococcus species. Staphylococci 
have the ability to form biofilms on an implanted medical device or damaged tissues and these biofilms are difficult to eradicate. ${ }^{21}$ The highest antibiofilm activity documented for ethanol $80 \%$ extract $95.2 \%$ and ethyl acetate extract $93.9 \%$ against Staphylococcus aureus, while the lowest documented for ethanol $80 \%$ extract $55.4 \%$ and ethyl acetate extract $59.3 \%$ against Streptococcus mitis (Table 3 and 4). However, none of the extracts was able to inhibit biofilm formation completely this may be due to solubility and diffusion of phytochemical constituents in agar media. The antibiofilm activity of the seed extracts against Streptococcal and Staphylococcal species may be an important tool for decrease microbial colonization on the surfaces and the epithelial mucosa which is main causes of infections by interrupting the release of the adhesion compound lipoteichoic acid from the cell surface, ${ }^{24}$ or alteration of bacterial gene expression could be mediated the anti-biofilm action. ${ }^{25}$ As a result concluded that the antibacterial and antibiofilm activity of Ammi majus seed due to their bioactive constituent present in it because phenolic acid, terpenes, tannin and flavonoids ${ }^{10,26-29}$ were found to exhibit marked antibacterial and antibiofilm activity.

\section{Conclusion}

As a result concluded that during use of a different solvent for extraction of active constituents ethanol $80 \%$ extract showed higher activity than ethyl acetate extract against bacterial species, Ammi majus seed extracts revealed highest antibacterial activity against Streptococcus species and strongest antibiofilm activity on Staphylococcus species. A number of constituents (Ea 1-3 and E80 \% 1-4) revealed their activity by agar overlay method and future works were suggested for isolation and identification each of these constituents responsible for antibacterial activity by using a different instrument like TLC, HPLC, IR, NMR, etc.

\section{Conflicts of interest}

The authors report no conflicts of interest.

\section{References}

1. Guarrera PM. Traditional phytotherapy in Central Italy (Marche, Abruzzo, and Latium). Fitoterapia 2005; 76:1-25.

2. Høiby N, Bjarnsholt T, Givskov M, Molin S, Ciofu O. Antibiotic resistance of bacterial biofilms. Int $\mathrm{J}$ Antimicrob Agents 2010; 35(4):322-32.

3. Hugo WB, Russell AD. Pharmaceutical Microbiology, $7^{\text {th }}$ edn. USA: Blackwell publishing company; 2004. p. 3-38.

4. Parsek M, Greenberg. Socio microbiology: the connections between quorum sensing and biofilms. Trends in Microbiol 2004; 13:3-27.

5. Roland PS. Chronic suppurative otitis media: a clinical overview. Ear Nose Throat J 2002; 81:8 -10 .

6. Head NE, Yu HW. Cross-sectional analysis of clinical and environmental isolates of Pseudomonas aeruginosa: Biofilm formation, virulence and genome diversity. Infect Immun 2004; 72:133-44.

7. Essawi T, Srour M. Screening of some Palestinian medicinal plants for antibacterial activity. J Ethnopharmacol 2000; 70:343-9.

8. Knetsch MLW, Koole LH. New strategies in the development of antimicrobial coatings: the example of increasing usage of silver and silver nanoparticles. Polym 2011; 3:340-66.

9. Sagar S, Kaistha DS. Virulence profile of an emerging coagulase negative Staphylococcus auricularis NC clinical isolate. J Pure Appl Microbiol 2011; 5(2):787-92.

10. Nostro A, Roccaro AS, Bisignano G, Marino A, Cannatelli MA, Pizzimenti FC et al. Effects of oregano, carvacrol, and thymol on Staphylococcus aureus and Staphylococcus epidermidis biofilms. J Med Microbiol 2007; 56(4):519-23.

11. Standar K, Kreikemeyer B, Redanz S, Münter LW, Laue M, Podbielski A. Setup of an in vitro test system for basic studies on biofilm behavior of mixed-species cultures with dental and periodontal pathogens. PLOS One 2010; 5(10):1-14.

12. Central Council for Research in Unani Medicine. Standardization of single drugs of Unani medicine - Part I. New Delhi, Ministry of Health and Family Welfare; 1987. p. 182-4.

13. Saeed MA, Khan F Z. Studies on the contact dermatitis properties of Indigenous Pakistani medicinal Plants. J Faculty Pharm Gazi Univer 1994; 11(1):17-24.

14. Lin J, Zhan SM, Wu K, Willett WC, Fuchs CS, Giovannucci E. Flavonoid intake and colorectal cancer in men and women. Am J Epidemiol 2006; 164:644-51.

15. Abdulla WA. Preliminary studies on the anti-schistosomal effect of Ammi majus L. Egypt J Bilharziasis 1978; 4:19-26. 
16. Shihab H. Mutlag. Dose-Dependent Anti-inflammatory effect of Ammi majus alcoholic extract in the rat: Chronic study. Iraqi J Pharm Sci 2012; 21(1):82-6.

17. Alupuli A, Calinescu I, Lavric V. Ultrasonic vs. microwave extraction intensification of active principles from medicinal plants. AIDIC Conference Series 2009; 09:1-8.

18. Maidment C, Dyson A, Haysom I. A study into the antimicrobial effects of cloves (Syzygium aromaticum) and cinnamon (Cinnamomum zeylanicum) using disc diffusion assay. Nutr Food Sci 2006; 36(4):225-30.

19. Silva MT, Simas SM, Batista TG, Cardarelli $P$, Tomassini TC. Studies on antimicrobial activity, in vitro, of Physalis angulata L.(Solanaceae) fraction and physalin B bringing out the importance of assay determination. Mem Inst Oswaldo Cruz 2005; 100:779-82.

20. Teanpaisan R, Senapong S, Puripattanavong J. In vitro antimicrobial and antibiofilm activity of Artocarpus Lakoocha (Moraceae) Extract against Some Oral Pathogens. Trop J Pharm Res 2014; $13(7): 1149-55$

21. Raja A, Ali F, Khan I. Antistaphylococcal and biofilm inhibitory activities of acetyl-11-keto- $\beta$ boswellic acid from Boswellia serrata. BMC Microbiol 2011; 11:54-62.

22. Dogruoz N, Zeybek Z, Karogoz A. Antibacterial activity of some plants extracts. J Biol 2008; 67 (1):17-21.

23. Al-Hadidi AK, Al-Numan YA, Al-Daody CA. The interaction between some phenolic compounds in Ammi majus herb: (khillah) extracts and antibiotics against some selected bacterial isolates in vitro. Raf J Sci 2013; 24(2):17-30.

24. Bavington C, Page C. Stopping bacterial adhesion: a novel approach to treating infections. Respir 2005; 72:335-44.

25. Dean SN, Bishop BM, van Hoek ML. Natural and synthetic cathelicidin peptides with anti-microbial and anti-biofilm activity against Staphylococcus aureus. BMC Microbiol 2011; 11:114.

26. Ergün B, Çoban T, Onurdag F, Banoglu E. Synthesis, antioxidant and antimicrobial evaluation of simple aromatic esters of ferulic acid. Arch Pharmacal Res 2011; 34(8):1251-61.

27. Nostro A, Marino A, Blanco AR. In vitro activity of carvacrol against Staphylococcal preformed biofilm by liquid and vapor contact. $\mathrm{J}$ Med Microbiol 2009; 58(6):791-7.

28. Lee JH, Park JH, Cho HS, Joo SW, Cho MH, Lee $\mathrm{J}$. Anti-biofilm activities of quercetin and tannic acid against Staphylococcus aureus. Biofouling 2013; 29(5):491-9.

29. Adham NA. Comparative extraction methods, fluorescence, qualitative and quantitative evaluation of Ammi majus seed extracts. J Pharmacogn Phytochem 2015; 4(1):41-4. 